\title{
Lead Exposure Induces Structural Damage, Digestive Stress, Immune Response and Microbiota Dysbiosis in Intestine of Silver Carp (Hypophthalmichthys Molitrix)
}

Haisu Liu Jinan University

Hang Zhang

Hubei Water Resources and Hydropower Science and Technology information Center

Sanshan Zhang

South China Normal University

Anli Wang

South China Normal University

Shengli Fu ( $\nabla$ fushengli@m.scnu.edu.cn )

South China Normal University https://orcid.org/0000-0001-7295-9032

\section{Research Article}

Keywords: Lead, Silver carp, 16S rRNA, Intestinal microbiota, Immune function

Posted Date: November 16th, 2021

DOI: https://doi.org/10.21203/rs.3.rs-1046012/v1

License: (c) (1) This work is licensed under a Creative Commons Attribution 4.0 International License.

Read Full License 


\section{Abstract}

Lead $(\mathrm{Pb})$ is one of the most common toxic heavy metals in water, and it can cause harm to aquatic animals and humans when released into the environment. In the present study, the effects of $\mathrm{Pb}$ exposure on the morphology, digestive enzyme activity, immune function and microbiota structure of silver carp (Hypophthalmichthys molitrix) intestines within $96 \mathrm{~h}$ were detected. Moreover, the correlation between them was analyzed. The results showed that $\mathrm{Pb}$ exposure could severely damage the intestinal morphology on the one hand, including significantly shortening the intestinal villi's length, increasing the goblet cells' number, causing the intestinal leukocyte infiltration, and thickening the intestinal wall abnormally, and on the other hand, increasing the activity of intestinal digestive enzyme (trypsin and lipase). In addition, the mRNA expressions of structure-related genes (Claudin-7 and villin-7) were downregulated, and the immune factors (IL-8, IL-10 and TNF- $a$ ) were up-regulated after $\mathrm{Pb}$ exposure. Furthermore, data of the MiSeq sequencing showed that the abundance of membrane transport, immune system function and digestive system of silver carp intestinal microbiota was decreased, and the cellular antigens was increased. Finally, the canonical correlation analysis (CCA) found that there were correlations between silver carp's intestinal microbiota and intestinal morphology and immune factors. In conclusion, it is speculated that $\mathrm{Pb}$ may damage the intestinal barrier of silver carp, leading the microbiota dysbiosis, which further affects the intestinal immune and digestive function.

\section{Introduction}

In recent years, industrialization and related human activities have led to a significant increase in heavy metal content in freshwater environment (Sin et al. 2001; Yuan et al. 2011; Islam et al. 2015). A large number of studies have shown that metals pollutants in the water have negative effects on aquatic organisms, such as serious harm to freshwater and aquatic microorganisms (Kawser et al. 2016; Mohammad et al. 2018; Pradip et al. 2019). In addition, excessive accumulation in fish can even cause toxicity to humans through the food chain (Vargas et al. 2001; Odokuma and O. ljeomah 2004; Tao et al. 2012). Lead (Pb), as one of the most common pollutants, is carcinogenic, teratogenic and to a certain extent mutagenic to animals like most other heavy metals (Eisler 1998; Bonacker et al. 2005).

Several studies have reported that $\mathrm{Pb}$ pollution may affect the structure and function of fish intestines, cause fish intestinal morphology disturbance, and affect the activity of intestinal enzymes activity and immune function (Crespo et al. 2006; Lei et al. 2020). In addition, it is reported that the stability of intestinal structure and function is closely related to the intestinal microbiota structure ( $\mathrm{Ni}$ et al. 2009), and the studies have shown that water pollutants can destroy the structure of fish intestinal microbiota and cause harm to the physiological functions of fish intestines (Qiao et al. 2019a).

Intestinal microbiota is an important ecosystem in organism, which has a lot to do with metabolism and immunity, and affects the growth, survival and lipid synthesis mechanism of fish (O'Hara and Shanahan 2006; Carmody and Turnbaugh 2012; Daga et al. 2013; Bahrami et al. 2014; Wang et al. 2019). There are many studies on the influence of foreign substances on the structure of fish intestinal microbiota, such 
as immunosuppression changed the intestinal microbiota structure of the silver carp, which in turn increased the susceptibility to pathogens (Qi et al. 2019). Although previous studies have suggested that heavy metal has a toxic effect on aquatic organisms, the relevant influence mechanism among the intestinal microbiota, intestinal structure, and intestinal function of fish under $\mathrm{Pb}$ exposure is still unclear.

Fish is one of the most important aquatic organisms in the aquatic environment and plays a key-role in human diet and provides an important source of high-quality protein (Milenkovic et al. 2019). Over the last twenty years, world consumption of fish has increased with increasing concerns about its therapeutic and nutritional benefits (Rajeshkumar and Li 2018). Among them, silver carp is one of the most common freshwater fish species in the environment, and is well-known as a food fish in many countries (Buchtova and Frantisek 2011; Islam et al. 2019). Meanwhile, silver carp as a filter-feeding fish, can reduce phytoplankton biomass, control algae bloom, and promote nutrient regeneration in water environment (Fu et al. 2020). Therefore, silver carp plays an important role in maintaining the balance of the water environment. In this study, we simulated the basic environment of the pond, and added $\mathrm{Pb}$ pollution. We found that $\mathrm{Pb}$ was accumulated in the intestine, and the intestinal structure, digestive enzyme activity, and the expression of immune factors was changed after $\mathrm{Pb}$ pollution. Then, the dynamics of microbiota in silver carp intestine were detected and analyzed.

\section{Materials And Methods}

Fish maintenance

Purchased silver carp from an aquaculture company in Qingyuan (Guangdong, China), transported to the experimental base in oxygenated polythene bag, and then cultured in an earthen pond The average body length of silver carp was $10.72 \pm 0.35 \mathrm{~cm}$ and the average weight was $12.31 \pm 0.54 \mathrm{~g}$. Before sampling, fish were fed twice a day with a commercial fish food for two weeks as describe before (Liu et al. 2020). During domestication, silver carp has no clinical symptoms (normal swimming and active eating).

Exposure treatment and sample collection

According to the Pirsaheb's method, acute toxicity test and lethal concentration $\left(\mathrm{LC}_{50}\right)$ test at $96 \mathrm{~h}$ of $\mathrm{Pb}\left(\mathrm{NO}_{3}\right)_{2}$ were carried out (Pirsaheb et al. 2019). Referring to the method of EPA (version 1.5), design various concentrations of $\mathrm{Pb}\left(\mathrm{NO}_{3}\right)_{2}$ to determine the $\mathrm{LC}_{50}$ of the silver carp by a series of pre-experiments for acute toxicity tests (Protection Agency 2002). Then, confirmed the safe concentration (SC, SC $=\mathrm{LC}_{50} \times$ 0.1) of the silver carp according to the previous method (Roopadevi and K Somashekar 2012).

Eighty silver carp were randomly selected from the pond and cultured in a four cubic meter of aquarium (to simulate fish original living environment, the culture water is taken directly from the local ponds where the fish originally lived). Before $\mathrm{Pb}$ exposure, twelve silver carp were randomly collected and sampled (L0 $\mathrm{h}$ group). Then, fish were exposed to a SC $(3.84 \mathrm{mg} / \mathrm{g})$ of $\mathrm{Pb}\left(\mathrm{NO}_{3}\right)_{2}$ until $96 \mathrm{~h}$, and twelve silver carp were randomly collected at $6 \mathrm{~h}, 48 \mathrm{~h}$ and $96 \mathrm{~h}$ (L6 h, L48 h and L96 h group), respectively. The Pb content in 
water was keep around $3.84 \mathrm{mg} / \mathrm{L}$ during the experiment. Before sampling, fish were anesthetized in $0.05 \%$ MS-222 (Aladdin, China) to euthanize, posterior intestines from each group were sampled to detect the activities of digestive enzyme, $\mathrm{Pb}$ content, and RNA expression of gene $(\mathrm{n}=3)$. The samples were immediately stored frozen liquid nitrogen and stored at $-80^{\circ} \mathrm{C}$ until analysis. For histological analyses, posterior intestines were collected from the fish euthanized and fixed in $4 \%$ paraformaldehyde solution (n = 3). For DNA Extraction and MiSeq sequencing, posterior intestines from the fish euthanized were collected and fixed in $95 \%$ alcohol $(n=3)$.

\section{$\mathrm{Pb}$ accumulation}

Posterior intestines from each group were sampled to detect $\mathrm{Pb}$ concentration. According to the method published by previous study, the Pb concentrations were measured (Liu et al. 2020). Briefly, the samples were collected and homogenized, using the $4 \mathrm{~mL} \mathrm{HNO}_{3}$ to digest for $1 \mathrm{~h}$, and then put into microwave digestion apparatus (QiYao, China). Microwave digestion procedure: hold at $120^{\circ} \mathrm{C}$ for $10 \mathrm{~min}$, hold at $150^{\circ} \mathrm{C}$ for $15 \mathrm{~min}$, and then hold at $190^{\circ} \mathrm{C}$ for $25 \mathrm{~min}$. After that, the $\mathrm{Pb}$ concentration of the sample was determined by ICP-MS (Liu et al. 2020).

Histological analysis

For histological analysis, using $4 \%$ paraformaldehyde solution (Biosharp, China) to fix the posterior intestine ( $1 \mathrm{~cm}$ segment before the anus) of all samples (each group, $n=3$ ) for $48 \mathrm{~h}$, and then processed according to the method described before (Liu et al. 2021). Using the light microscope (Nikon, Japan) to observe the number of goblet cells, intestinal villi, infiltration of leucocyte and wall thickness.

Digestive enzyme activities analysis

For digestive enzymes activities analysis, obtain intestinal homogenate: mix the intestine with saline solution in a ratio of $1: 9$, mechanical homogenate, and ice bath for 3-5 min to prepare tissue homogenate. Then, the intestinal homogenate was centrifuged at $4,000 \times g$ for 10 min at $4{ }^{\circ} \mathrm{C}$, and the supernatant was collected. Finally, use the total protein assay kit (Jiancheng, China), trypsin assay kit (Jiancheng) and lipase assay kit (Jiancheng) to determine the trypsin and lipase enzymes activities of silver carp intestine according to the manufacturer's instructions.

Quantitative real-time PCR for analysis intestinal structure and immune-related genes

Using Trizol reagent (Vazyme, China) to extract the total RNA of sample according to the method published by previous study. Briefly, tissues (100 mg / samples) were collected and ground under liquid nitrogen conditions, lysed with $1 \mathrm{~mL}$ Trizol, and RNA was extracted with chloroform and isopropanol. Dissolved RNA in DEPC-treated water. Dissolved the RNA in DEPC-treated water and then determined the RNA concentration and quality according to the previous method (Tan et al., 2018). Using SYBR ${ }^{\circledR}$ qPCR Master Mix (Vazyme, Nanjing, China) and the Bio-Rad CFX Connect PCR (Bio-Rad, USA) to performe the quantitative real-time PCR (qRT-PCR). The $\beta$-actin of the silver carp was used as a reference gene 
(GenBank accession NO. JX274220.1). The primers of gene shown in Tab. 1. Detected the primer's efficiency and specificity before the qRT-PCR analysis and processed the qRT-PCR as the method of Fu et al (Fu et al. 2019).

Table 1 The primer sequences used in this study for qRT-PCR.

\begin{tabular}{|ll|}
\hline Primers & Nucleotide Sequence $\left(5^{\prime} \rightarrow 3^{\prime}\right)$ \\
\hline RT- $\beta$-actin-F & TCTGGTGAAGGCTGGTTTTGC \\
\hline RT- $\beta$-actin-R & CTTTCTGACCCATACCGACCAT \\
RT-IL-8-F & TGTTGCTGTGGCATTTCTGACC \\
RT-IL-8-R & CAGTGAGGGCTGGGAGGGTA \\
RT-TNF- $\alpha$-F & CAAAGTCAGGCGTATGGCGG \\
RT-TNF- $\alpha$-R & TGGCAGCCCTGGAAGTGG \\
RT-IL-10-F & AATCCCTTTGAGTTTGCCACC \\
RT-IL-10-R & TGCTTTTCTCTCTTTGATGCCA \\
RT- - illin-1-F & CTTGTGCCCTGTCCACCTAATA \\
RT- illin-1-R & GCCTTGCCCAGCCAATAAT \\
\hline RT- Claudin-7-F & CAAGGTGTACGACTCCATCCTACA \\
\hline RT- Claudin-7-R & CACTTCATGCCCATGCTGG \\
\hline
\end{tabular}

DNA Extraction

The posterior intestinal samples of all groups (each group, $n=3$ ) were sent to Guangzhou JiRui Gene Technology Co. Ltd. (China) for extraction of DNA and PCR amplification by Illumina MiSeq Sequencing platform. PCR was performed from V3 V4 variable regions of $16 \mathrm{~S}$ rRNA to taxonomically identify the bacteria (Xun et al. 2019).

16S rRNA gene amplification sequence analysis

Constructed and sequenced the high-throughput sequencing library according to previous methods (Abdolrasouli et al. 2015; Yang et al. 2015). The "CCTACGGRRBGCASCAGKVRVGAAT" sequence as the upstream primers and "GGACTACNVGGGTWTCTAATCC" sequence as the downstream primers were used to amplify the DNA samples, including V3 and V4 (two highly variable regions). In addition, the PCR product of $16 \mathrm{~S}$ rDNA was subjected to NGS sequencing. Finally, read the sequence information of the sample and determine the library quality.

\section{Data analysis}


The results were analysed by SPSS 19.0 (SPSS Inc., Michigan Avenue, Chicago, IL, USA) and R. Using image pro plus program to analyze intestinal structure indicators. One-way ANOVA was used to check for the significance of difference between the means of each group. Data were expressed as (Mean \pm S.D.). Difference was considered significant at $0.01<p<0.05\left(^{*}\right)$. Extremely significantly difference was considered significant at $p<0.01(* *)$.

\section{Results}

$\mathrm{Pb}$ accumulation in intestines

Determining the $\mathrm{Pb}$ concentration of silver carp intestine by ICP-MS. As shown in Fig. 1, the concentration of $\mathrm{Pb}$ in intestines significantly increased to the highest concentration $(118.39 \mathrm{mg} / \mathrm{kg})$ at $96 \mathrm{~h}$ after $\mathrm{Pb}$ exposure.

Histologic observations and analysis of intestines

Observing the morphology of silver carp intestines by a microscope (Nikon, Japan) (Fig. 2A). As shown in Fig. 2B, after $\mathrm{Pb}$ exposure for $48 \mathrm{~h}$, the relative intestinal wall thickness was increased significantly and reached the highest level (up to 1.27-fold, $p<0.01$ ). Besides, the relative depth of intestinal crypts decreased and reached the lowest level at $96 \mathrm{~h}$ (down to 0.41 -fold, $p<0.01$ ) (Fig. 2C), while the goblet cells' number in intestine increased and reached the highest level at $48 \mathrm{~h}$ (up to 3.17-fold, $p<0.01$ ) (Fig. 2D).

The activity levels of trypsin and lipase in the intestines

Using the enzyme activity kit to determine the relative activity level of trypsin activity and lipase activity of silver carp intestine after $\mathrm{Pb}$ exposure. As shown in Fig. 3A, the relative activity of trypsin in the intestine increased significantly and reached the highest level after $6 \mathrm{~h}$ of Pb exposure (up to 6.38-fold, $p<0.01$ ). Similarly, the relative activity level of lipase increased significantly and reached the highest level after 48 h (up to 3.55 -fold, $p<0.01$ ) (Fig. 3B).

The expression of immune and structure -related genes in the intestines

The mRNA expressions of immune-related genes (IL-8, IL-10 and TNF- $a$ ) and structure-related genes (Claudin-7 and villin-1) in intestine were measured by qRT-PCR. After Pb exposure, as shown in Fig. 4A and $B$, the expression of TNF- $a$ and $I L-10$ in intestine significantly increased to the highest level at $48 \mathrm{~h}$ (up to 2.36-fold, $p<0.01$, and 2.28-fold, $p<0.01$, respectively) after $\mathrm{Pb}$ exposure and gradually recovered at $96 \mathrm{~h}$. In Fig. 4C, the expression of $I L-8$ in intestine significantly increased to the highest level at $6 \mathrm{~h}$ (up to 2.76 -fold, $p<0.01$ ) and gradually recovered later. On the contrary, the expression of Claudin-7 and villin-1 in intestine decreased significantly and reached the lowest level at $6 \mathrm{~h}$ after $\mathrm{Pb}$ exposure (down to 0.31 -fold, $p<0.01$, and 0.11 -fold, $p<0.01$, respectively) (Fig. 4D and E).

Characteristics of fish microbiota structures and diversity analysis 
Quality and chimera filtration from effective sequences ranging 21,252 to 101,185 (each group, $\mathrm{n}=3$ ) per sample by Illumina MiSeq platform, a total of 779,971 quality-filtered sequences were obtained. A $97 \%$ similarity cutoff was applied to cluster the high-quality sequences of the microbiota in intestines which divided into 615 operational taxonomic units (OTUs) (excluding monad sequence). Among them, 324 OTUs were shared by all samples (Fig. S1).

Good's coverage of different samples was more than 99\% (Tab. 2), and the statistical estimates of species richness and diversity indexes from each sample were presented in Tab. 2. ACE index ranged from 261.56 to 354.71 , while chao1 index ranged from 261.07 to 362.55 . The trends of ACE and chao1 after $\mathrm{Pb}$ exposure were shown in Fig. $5 \mathrm{~A}$ and $\mathrm{B}$. The shannon index ranged from 5.12 to 6.22 , while the simpson index ranged from 0.90 to 0.97 . In all samples, the shannon index and simpson index were the lowest at $48 \mathrm{~h}$ after $\mathrm{Pb}$ exposure (Fig. $5 \mathrm{C}$ and $\mathrm{D}$ ). The corresponding rarefaction curves tended to reach the saturation plateau (Fig. S2).

Table 2 Diversity and Richness indexes as calculated by MOTHUR software (ver. 1.30.0). Operational taxonomic units (OTUs) are defined at $97 \%$ sequence similarity.

\begin{tabular}{|c|c|c|c|c|c|c|c|}
\hline \multirow[t]{2}{*}{ Samples } & \multirow{2}{*}{$\begin{array}{l}\text { Total sequences } \\
\text { passed quality } \\
\text { check }\end{array}$} & \multirow{2}{*}{$\begin{array}{l}\text { Total } \\
\text { OTUs }\end{array}$} & \multicolumn{4}{|c|}{ Diversity and Richness indexes ${ }^{1}$} & \multirow{2}{*}{$\begin{array}{l}\text { Good's } \\
\text { coverage }\end{array}$} \\
\hline & & & $\begin{array}{l}\text { Ace } \\
\text { Index }\end{array}$ & $\begin{array}{l}\text { Chao1 } \\
\text { Index }\end{array}$ & $\begin{array}{l}\text { Simpson } \\
\text { Index }\end{array}$ & $\begin{array}{l}\text { Shannon } \\
\text { Index }\end{array}$ & \\
\hline LO h & 221,047 & 884 & $\begin{array}{l}261.56 \\
\pm 11.25\end{array}$ & $\begin{array}{l}261.07 \\
\pm 8.99\end{array}$ & $\begin{array}{l}0.96 \pm \\
0.01\end{array}$ & $\begin{array}{l}5.85 \pm \\
0.24\end{array}$ & 0.999 \\
\hline L6 h & 231,612 & 958 & $\begin{array}{l}273.66 \\
\pm 47.05\end{array}$ & $\begin{array}{l}273.07 \\
\pm 46.12\end{array}$ & $\begin{array}{l}0.97 \pm \\
0.03\end{array}$ & $\begin{array}{l}6.22 \pm \\
0.82\end{array}$ & 0.997 \\
\hline L48 h & 122,601 & 905 & $\begin{array}{l}265.86 \\
\pm 28.48\end{array}$ & $\begin{array}{l}271.32 \\
\pm 29.39\end{array}$ & $\begin{array}{l}0.90 \pm \\
0.04\end{array}$ & $\begin{array}{l}5.12 \pm \\
0.79\end{array}$ & 0.998 \\
\hline L96 h & 204,711 & 844 & $\begin{array}{l}354.71 \\
\pm \\
103.11\end{array}$ & $\begin{array}{l}362.55 \\
\pm \\
102.98\end{array}$ & $\begin{array}{l}0.96 \pm \\
0.02\end{array}$ & $\begin{array}{l}6.02 \pm \\
0.96\end{array}$ & 0.999 \\
\hline
\end{tabular}

1: Values represent the average \pm S.D (each mean value of 3 determinations).

Change in the bacterial community compositions

Main bacterium of silver carp at the phylum level was shown in Fig. 6, mainly including Proteobacteria, Firmicutes, Bacteroidetes, Cyanobacteria, and Fusobacteria. Before $\mathrm{Pb}$ exposure, the most abundant bacterium in intestine was Proteobacteria (29.47\%). After $\mathrm{Pb}$ exposure, the most abundant bacterium in intestine was changed to Firmicutes (36.05\%) at $6 \mathrm{~h}$ and then changed to Bacteroidetes at $48 \mathrm{~h}(39.50 \%)$ and Proteobacteria at $96 \mathrm{~h}(33.37 \%)$.

In Fig. 7A, 29 different family of microbiota were confirmed in silver carp's intestine and six of them were dominant. They were Aeromonadaceae, Weeksellaceae, Burkholderiaceae, Flavobacteriaceae, and 
Erysipelotrichaceae. After $\mathrm{Pb}$ exposure for $6 \mathrm{~h}$, the abundance of Aeromonadaceae in intestines were increased significantly and reached to the highest level (Fig. 7B). The relative abundance of Weeksellaceae and Burkholderiaceae significantly increased to the highest level at $48 \mathrm{~h}$, and then recovered (Fig. 7C and D).

Canonical correlation analysis

CCA was carried out to analyze the relationship between intestinal microbiota, intestinal structure, immune factors, digestive factor, and $\mathrm{Pb}$ content. As shown in Fig. 8A, the goblet cell number was positively correlated with the intestinal microbial community in $L 48 \mathrm{~h}$ group, the intestinal crypt was correlation with intestinal microbial community in $\mathrm{LO} \mathrm{h}$ and $\mathrm{L} 6 \mathrm{~h}$ groups, and the $\mathrm{Pb}$ content was positively correlated with the intestinal Pb content in L96 h group. In Fig. 8B, the expression of TNF- $a$ and $I L-10$ in silver carp were positively correlated with the intestinal microbial community in L48 $\mathrm{h}$ group. Meanwhile, the expression of $I L-8$ correlated with intestinal microbial community in L6 h group. In Fig. 8C, the expressions of trypsin and lipase in intestine were correlated with intestinal microbial community in L6 $\mathrm{h}$ and L48 $\mathrm{h}$ groups, respectively.

Predictive functional profiling of microbial communities

PICRUST was used to predictive the functions of the microbiota in intestines. In Fig. 9A, 25 functions were identified by Cluster of Orthologous Groups of proteins (COG) analysis in this study. In COG analysis, except for general function prediction only (relative abundance from 11.48 to $11.72 \%$ ), the highest represented category was transcription (7.04 to $8.07 \%$ ) and amino acid transport and metabolism ( 7.87 to $8.20 \%$ ) function categories. These COG function classification results indicated that the biological functions profiles of all groups were similar with each other.

Based on the Kyoto Encyclopedia of Genes and Genomes (KEGG) analysis, the functions of microbiota in carp intestinal were divided into six categories at level one, namely genetic information processing, cellular processes, human diseases, environmental information processing, metabolism and organismal systems, among which metabolism (47.54-49.26\%) was the most abundant (Fig. 9B). At level two, membrane transport (10.94-12.94\%) was the most abundant, while immune system and digestive system was the lower abundant but significant changes (Tab. S1). Similarly, cellular antigens had a significant change at level three (Tab. S2). The relative abundance change of membrane transport, immune system, digestive system and cellular antigens were shown in Fig. 9C, D, E and F, respectively. The relative abundance of membrane transport function of intestinal microbiota significantly decreased to the lowest level at $48 \mathrm{~h}$, and the relative abundance of immune system function of microbiota also decreased at $6 \mathrm{~h}$. In contrast, the relative abundance of digestive system and cellular antigens function of intestinal microbiota increased consistently and reached the highest level at $48 \mathrm{~h}$.

\section{Discussion}


Nowadays, the water environment is generally polluted by heavy metals, which seriously affects the survival of fish in the water (Luczynska et al. 2018). Pb may cause damage to human nerves, hematopoietic system and kidneys (Sivaperumal et al. 2007; Hasschon et al. 2008). It has been reported that the accumulation of $\mathrm{Pb}$ in fish may adversely affect the structure and function of fish intestines. In this study, we found that $\mathrm{Pb}$ was enriched in the intestine of silver carp and the changes in the morphological structure, digestive enzyme's activity, and immune factors of the fish intestine. In addition, we also used high-throughput sequencing technology to detect changes of microbiota in silver carp's intestine after $\mathrm{Pb}$ exposure. CCA analysis showed that there is a significant correlation between the silver carp's intestinal microbial community and intestinal structural indicators, digestive enzyme activity levels and immune factors. The function prediction analysis further indicated that the changes of silver carp intestinal structure and function may be related to the intestinal microbiota. Therefore, $\mathrm{Pb}$ may destroy the structure and function of carp intestine by destroying the composition of silver carp intestinal microbiota.

Previous studies reported that heavy metals exposure could influence the intestinal function such as active transport, immune response, and so on (Iturri and Peña 1986; Wang and Chen 2015). In this study, the concentration of $\mathrm{Pb}$ in the silver carp intestine was significantly increased after $\mathrm{Pb}$ exposure (Fig. 1). Moreover, the intestinal morphology changed after $\mathrm{Pb}$ exposure, including infiltrated leukocytes, increased goblet cells' number, shallowed the depth of crypts, and increased intestinal wall thickness (Fig. 2). Crypts and intestinal wall thickness changes are related to inflammation, and the goblet cells' number increased and leukocyte infiltration will further promote inflammation (Lofgren et al. 2002; Qiao et al. 2019b; Liu et al. 2020). These results were consistent with the mRNA expression of structure-related genes (Claudin-7 and villin-1) and immune-related genes (TNF- $a, I L-8$ and $I L-10$ ) (Fig. 4). Meanwhile, the activity levels of intestinal digestive enzyme (trypsin and lipase) also increased significantly after $\mathrm{Pb}$ exposure (Fig. 3), which may be due to the compensation mechanism triggered by the environmental stress (Zare et al. 1996; Cao et al. 2010; Babaei et al. 2020). The data at the genetic, protein and structural levels indicated that $\mathrm{Pb}$ exposure can cause physiological damage to the intestinal barrier, which may be related to intestinal digestive function and immune response.

Fish intestinal microbiota plays an important role in intestinal morphology, digestion and immunity (Liu et al. 2020). After $\mathrm{Pb}$ exposure, the diversity of silver carp intestinal microbiota decreased (Fig. 5). The reduction of the diversity of fish intestinal microbiota will cause disorders of intestinal structure and immune function, destroy digestive power and function, and lead to the occurrence of diseases (Kuno et al. 2016; Passos and Moraes 2017).

After $\mathrm{Pb}$ exposure, Firmicutes and Bacteroidetes became the most abundant bacterium at the phylum level in intestine (Fig. 6). Firmicutes, a common phylum in the intestines of fish (Burgos et al. 2018; Meng et al. 2020). The increase of Firmicutes in relative abundance in this study may be due to its higher tolerance to heavy metals (Guo et al. 2019). Bacteroidetes, a Gram-negative bacterium, which closely relate to the occurrence of intestinal inflammation (Marchesi et al. 2016). At the family level, both Aeromonadaceae, Burkholderiaceae and Weeksellaceae in silver carp intestines were increased after $\mathrm{Pb}$ 
exposure (Fig. 5). Aeromonadaceae, belonging to Gammaproteobacteria, is a common pathogenic bacterium in fishes, which destroys the intestinal lining, causes intestinal cell damage, promotes inflammation and alter intestinal morphology (Ring et al. 2004; Bhowmik et al. 2009; Dikow 2011; Mohamed et al. 2015). Burkholderiaceae is belonging to Betaproteobacteria, which can promote inflammation in various epithelial cells (Yang et al. 2006; Liu et al. 2020). This may be related to the upregulation of intestinal TNF- $a$ and $I L-8$. Weeksellaceae is a pathogen that can releases the proinflammatory cytokines and degrades intestinal glycoprotein (Ruseler-van et al. 1989; Nagy et al. 1998; Zhang et al. 2017). Glycoprotein is one of the main components of the intestinal epithelial cell membrane, which affects the structure of the epithelial membrane and the morphology of the intestinal villi (Quaroni et al. 1979; Gupta and Waheed 1992). So, the up-regulated of Weeksellaceae abundance may induce the intestinal morphology changes.

The CCA results showed the relationship between the intestinal microbiota and intestinal structure, immune factors, digestive enzyme, and $\mathrm{Pb}$ content in intestines, and the structure index in Fig. 8. As expected, CCA proved that increased expressions of immune factors (IL-8 IL-10 and TNF- $a$ ) and increased level of digestive enzyme (trypsin and lipase) activity in the intestines closely related to the change of carp intestinal microbial community. Previous studies have also found that changes in intestinal microbial structure can affect the morphology of intestinal structure, digestive function and the expression of immune factors in fish (Geovanny and Jose 2010; Navarrete et al. 2013; Passos and Moraes 2017; Gao et al. 2017). As a filter-feeding fish, the structure and function of silver carp intestines maybe more closely related to intestinal microbiota (Dong and Li 1994). The results in our study indicated that changes in intestinal microbiota could affect the structure and immune function of the intestine.

\section{Conclusion}

In this study, the effects of $\mathrm{Pb}$ exposure on silver carp intestinal structure, digestive enzyme, and immune function within $96 \mathrm{~h}$ were detected. Through CCA analysis, we speculated that these effects may be related to the changes of intestinal microbial community. In addition, the function prediction results were also consistent with the correlation analysis. Overall, the results of this present study provide new information about the toxic effects of $\mathrm{Pb}$ on silver carp and gain a better understanding of the relationship between intestinal microbes and intestinal structure and function.

\section{Declarations}

\section{Conflict of Interest}

The authors declare no conflict of interests

\section{Credit Author Statement}

Haisu Liu: Writing - review \& editing, Investigation, Visualization. 
Hang Zhang: Investigation, Writing - review \& editing:; Investigation.

Sanshan Zhang: Writing - review \& editing, Resources.

Anli Wang: Writing - review \& editing.

Shengli Fu: Conceptualization, Writing - review \& editing, Investigation, Resources.

Acknowledgments This project was supported by Guangzhou Science and Technology Program Key projects (201804020058), Natural Science Foundation of Guangdong Province, China (2020A1515111121).

Data Availability Statements All data generated or analysed during this study are included in this published article (and its supplementary information files).

Funding This project was supported by Guangzhou Science and Technology Program Key projects (201804020058), Natural Science Foundation of Guangdong Province, China (2020A1515111121).

\section{Compliance with ethical standards}

Ethics statement All animal experimental procedures were carried out in accordance with the Regulations for Animal Experimentation of South China Normal University (SCNU-SLS-2020-001), and the animal facility was based on the National Institutes of Health guide for the care and use of Laboratory Animals (NIH Publications No. 8023).

\section{References}

1. Abdolrasouli A, Rhodes J, Beale MA, Hagen F, Rogers TR, Chowdhary A, Meis J, Armstrong JD, Fisher $M(2015)$ Genomic context of azole resistance mutations in aspergillus fumigatus determined using whole-genome sequencing. Mbio 6. https://doi.org/10.1128/mBio.00939-15

2. Babaei $S$, Abdolmohammad AK, Mahmood Naser, Mohammad AYS, Isidoro M (2020) Impact of starvation on digestive enzymes activities and plasma metabolites in Siberian sturgeon (Acipenser baerii, Brandt, 1869). Aquac Res 51:1-11. https://doi.org/10.1111/are.14515

3. Bahrami BS, Paykan HF, Mostafa A, Dorafshan S (2014) The dietary wood betony, stachys lavandulifolia vahl extract as a growth promoter and immune enhancer in common carp (Cyprinus carpio). Iran J Vet Res 15:359-363

4. Bhowmik P, Bag PK, Hajra TK, De R, Sarkar P, Ramamurthy T (2009) Pathogenic potential of Aeromonas hydrophila isolated from surface waters in Kolkata, India. J Med Microbiol 58:15491558. https://doi.org/10.1099/jmm.0.014316-0

5. Bonacker D, Stoiber T, Bohm KJ, Prots I (2005) Genotoxicity of inorganic lead salts and disturbance of microtubule function. Environ Mol Mutagen 45:346-353. https://doi.org/10.1002/em.20100 
6. Buchtova H, Frantisek J (2011) A new look at the assessment of the silver carp (Hypophthalmichthys molitrix Val.) as a food fish. Czech J Food Sci 29:487-497. https://doi.org/10.17221/392/2010CJFS

7. Burgos FA, Ray CL, Arias CR (2018) Bacterial diversity and community structure of the intestinal microbiome of Channel Catfish (Ictalurus punctatus) during ontogenesis. Syst Appl Microbiol 41. https://doi.org/10.1016/j.syapm.2018.04.006

8. Cao L, Huang W, Liu J, Yin X, Dou S (2010) Accumulation and oxidative stress biomarkers in Japanese flounder larvae and juveniles under chronic cadmium exposure. Comp Biochem Phys $\mathrm{C}$ 151:386-392. https://doi.org/10.1016/j.syapm.2018.04.006

9. Carmody RN, Turnbaugh PJ (2012) Gut microbes make for fattier fish. Cell Host Microbe 12:259261. https://doi.org/10.1016/j.chom.2012.08.006

10. Crespo S, Nonnotte G, Colin D, Leray C, Nonnotte L, Aubree A (2006) Morphological and functional alterations induced in trout intestine by dietary cadmium and lead. J Fish Biol 28:69-80. https://doi.org/10.1111/j.1095-8649.1986.tb05143.x

11. Daga P, Feijoo G, Moreira MT, Costas D, Villanueva AG, Lema JM (2013) Bioencapsulated probiotics increased survival, growth and improved gut flora of turbot (Psetta maxima) larvae. Aquacult Int 21:337-345. https://doi.org/10.1007/s10499-012-9556-y

12. Dikow RB (2011) Genome-level homology and phylogeny of Shewanella (Gammaproteobacteria: Iteromonadales: Shewanellaceae). BMC Genomics 12:237. https://doi.org/10.1186/1471-2164-12237

13. Dong S, Li D (1994) Comparative studies on the feeding capacity of silver carp and bighead carp. Chin J Oceanol Limnol 12:185-190. https://doi.org/10.1007/BF02850518

14. Eisler R (1998) Lead hazards to fish, wildlife, and invertebrates: A synoptic review. Biol Rep 85:1-94

15. Passos MDCF, Moraes FJP (2017) Intestinal microbiota in digestive diseases. Arq Gastroenterol 54:3

16. Fu S, Mingmei D, Liang Q, Yang Y, Chen M, Wei X, Wang A, Liao S, Ye J (2019) The key differentially expressed genes and proteins related to immune response in the spleen of pufferfish (Takifugu obscurus) infected by Aeromonas hydrophila. Fish Shellfish Immunol 91. https://doi.org/10.1016/j.fsi.2019.05.016

17. Fu YW, Luo JJ, Zhang QZ (2020) Ecological study of Carassotrema schistorchis in wild silver carp, Hypophthalmichthys molitrix. Int J Parasitol-Par 13:114-118. https://doi.org/10.1016/j.jppaw.2020.08.005

18. Gao X, Xie Q, Liu L, Kong P, Sheng J, Xiang H (2017) Metabolic adaptation to the aqueous leaf extract of Moringa oleifera Lam.-supplemented diet is related to the modulation of gut microbiota in mice. Appl Microbiol Biotechnol 101:5115-5130. https://doi.org/10.1007/s00253-017-8233-5

19. Geovanny DG, Jose LB (2010) A review on the interactions between gut microbiota and innate immunity of fish. Fems Immunol Med Mic 52:145-154. https://doi.org/10.1111/j.1574695X.2007.00343.x 
20. Guo Q, Li N, Xie S (2019) Heavy metal spill influences bacterial communities in freshwater sediments. Arch Microbiol 201. https://doi.org/10.1007/s00203-019-01650-y

21. Gupta PD, Waheed A (1992) Effect of starvation on glucose transport and membrane fluidity in rat intestinal epithelial cells. Febs lett 300:263-267. https://doi.org/10.1016/0014-5793(92)80859-F

22. Hasschon E, Bogut I, Rajkovic V, Bogut S, Cacic M, Horvatic J (2008) Heavy metal distribution in tissues of six fish species included in human diet, inhabiting freshwaters of the Nature Park "Hutovo Blato" (Bosnia and Herzegovina). Arch Environ Contam Toxicol 54:75-83. https://doi.org/10.1007/s00244-007-9008-2

23. Islam MS, Ahmed MK, Raknuzzaman M, Habibullah-Al-Mamun M, Islam MK (2015) Heavy metal pollution in surface water and sediment: A preliminary assessment of an urban river in a developing country. Ecol Indic 48:282-291. https://doi.org/10.1016/j.ecolind.2014.08.016

24. Islam M, Fang Y, Mahmud N, Jiang QX, Xia WS (2019) Effectiveness of combined acetic acid and ascorbic acid spray on fresh silver carp (Hypophthalmichthys molitrix) fish to increase shelf-Life at refrigerated temperature. Curr Res Nutr Food S 7:415-426. https://doi.org/10.12944/CRNFSJ.7.2.11

25. Iturri SJ, Peña A (1986) Heavy metal-induced inhibition of active transport in the rat small intestine in vitro. Interaction with other ions. Comp Biochem Physiol C: Pharmacol Toxicol Endocrinol 84:363368. https://doi.org/10.1016/0742-8413(86)90106-4

26. Kawser AM, Mohammad AB, Goutam KK, Saiful IM, Monirul IM, Muzammel HM (2016) Human health risks from heavy metals in fish of Buriganga river. Bangladesh Springerplus 5:1697. https://doi.org/10.1186/s40064-016-3357-0

27. Kuno T, Hirayama-Kurogi M, Ito S, Ohtsuki S (2016) Effect of intestinal flora on protein expression of drug-metabolizing enzymes and transporters in the liver and kidney of germ-free and antibioticstreated mice. Mol Pharm 13:2691-2701. https://doi.org/10.1021/acs.molpharmaceut.6b00259

28. Lei Z, Ya GZ, Yong HF, Mu YL, Gui QW, Yan FM (2020) Toxic effects of waterborne lead (Pb) on bioaccumulation, serum biochemistry, oxidative stress and heat shock protein-related genes expression in Channa argus. Chemosphere 261:127714. https://doi.org/10.1016/j.chemosphere.2020.128681

29. Liu HS, Fu SL, Zhang SS, Ding MM, Wang AL (2020) Lead induces structural damage, microbiota dysbiosis and cell apoptosis in the intestine of juvenile bighead carp (Hypophthalmichthys nobilis). Aquaculture $528 \mathrm{https} / / /$ doi.org/10.1016/j. aquaculture.2020.735573

30. Liu HS, Zhang SS, Qiu M, Wang AL,Ye JM, Fu SL (2021) Garlic (Allium sativum) and Fu-ling (Poria cocos) mitigate lead toxicity by improving antioxidant defense mechanisms and chelating ability in the liver of grass carp (Ctenopharyngodon idella). Ecotoxicology 30:885-898. https://doi.org/10.1007/s10646-021-02405-6

31. Lofgren M, Fagher K, Wede OK, Arner A (2002) Decreased shortening velocity and altered myosin isoforms in guinea-pig hypertrophic intestinal smooth muscle. J Physiol 544:707-714. https://doi.org/10.1113/jphysiol.2002.027060 
32. Luczynska J, Paszczyk B, Luczynski MJ (2018) Fish as a bioindicator of heavy metals pollution in aquatic ecosystem of Pluszne Lake, Poland, and risk assessment for consumer's health. Ecotox Environ Safe 153:60-67. https://doi.org/10.1016/j.ecoenv.2018.01.057

33. Marchesi JR, Adams DH, Fava F, Hermes GDA, Hirschfield GM, Hold G, Quraishi MN, Kinross J, Smidt H, Tuohy KM, Thomas LV, Zoetendal EG, Hart A (2016) The gut microbiota and host health: a new clinical frontier. Gut 65:1-10. https://doi.org/10.1136/gutjnl-2015-309990

34. Meng LJ, Zhang Y, Li XX, Liu JH, Wen B, Gao JZ, Chen ZZ (2020) Comparative analysis of bacterial communities of water and intestines of silver carp (Hypophthalmichthys molitrix) and bighead carp (H. nobilis) reared in aquaculture pond systems. Aquaculture 534:736334.

https://doi.org/10.1016/j.ecoenv.2018.01.057

35. Milenkovic B, Stajic JM, Stojic N, Pucarevic M, Strbac S (2019) Evaluation of heavy metals and radionuclides in fish and seafood products. Chemosphere 229:324-331. https://doi.org/10.1016/j.chemosphere.2019.04.189

36. Mohammad AB, Muzammel HM, Jhuma A, Shamshad BQ, Fajlul HSM, Atique UAKM, Firoz KM (2018) Concentration of heavy metals in seafood (fishes, shrimp, lobster and crabs) and human health assessment in Saint Martin Island, Bangladesh. Ecotox Environ Safe 159:153-163. https://doi.org/10.1016/j.ecoenv.2018.04.035

37. Mohamed T, Nashwa AEED, Ammar A, Mohamed A, Orabi A, Samir A (2015) Antibacterial activity of lactic acid bacteria (LAB) against significant fish pathogens. Inter J Vet Sci 4:145-147

38. Nagy E, Mándi Y, Szöke I, Kocsis B (1998) Induction of release of tumor necrosis factor and IL-6 from human mononuclear cells by Bacteroidesstrains. Anaerobe 4:133-138.

https://doi.org/10.1006/anae.1998.0151

39. Navarrete P, Fuentes P, De LFL, Barros L, Magne F, Opazo R, Ibacache C, Espejo R, Romero J (2013) Short-term effects of dietary soybean meal and lactic acid bacteria on the intestinal morphology and microbiota of Atlantic salmon (Salmo salar). Aquacult Nutr 19:827-836.

https://doi.org/10.1111/anu.12047

40. Ni Y, Zhong X, Wang H, Xu L, Wei S (2009) Effects of microbial agents on small intestinal structure and the quantity of cecal microorganisms in broilers. Front Agric China 3:84-88. https://doi.org/10.1007/s11703-009-0016-z

41. O'Hara AM, Shanahan F (2006) The gut flora as a forgotten organ. Embo Rep 7:688-693. https://doi.org/10.1038/sj.embor.7400731

42. Odokuma L, O.ljeomah S (2004) Tolerance of bacteria to toxicity of heavy metals in the New Calabar River. Glob J Environ Sci 2:128-132. https://doi.org/10.4314/gjes.v2i2.2419

43. Pirsaheb M, Azadi NA, Miglietta ML, Sayadi MH, Blahova J, Fathi M, Mansouri B (2019) Toxicological effects of transition metal-doped titanium dioxide nanoparticles on goldfish (Carassius auratus) and common carp (Cyprinus carpio). Chemosphere 215:904-915.

https://doi.org/10.1016/j.chemosphere.2018.10.111 
44. Pradip KM, Malika DS, Krishna KY, Amit K, Sandeep K, Hesam K (2019) Bioaccumulation and potential sources of heavy metal contamination in fish species in River Ganga basin: Possible human health risks evaluation. Toxicol Rep 6:472-481.

https://doi.org/10.1016/j.toxrep.2019.05.012

45. Protection Agency USE (2002) Methods for measuring the acute toxicity of effluents and receiving waters to freshwater and marine organisms. EPA 821-R-02-012.

46. Qi X, Tu X, Zha J, Huang A, Wang G, Ling F (2019) Immunosuppression-induced alterations in fish gut microbiota may increase the susceptibility to pathogens. Fish Shellfish Immunol 88:540-545. https://doi.org/10.1016/j.fsi.2019.03.035

47. Qiao R, Deng Y, Zhang S, Wolosker MB, Zhu Q, Ren H, Zhang Y (2019a) Accumulation of different shapes of microplastics initiates intestinal injury and gut microbiota dysbiosis in the gut of zebrafish. Chemosphere 236:124334. https://doi.org/10.1016/j.chemosphere.2019.07.065

48. Qiao R, Sheng C, Lu Y, Zhang Y, Ren H, Lemos B (2019b) Microplastics induce intestinal inflammation, oxidative stress, and disorders of metabolome and microbiome in zebrafish. Sci Total Environ 662:246-253. https://doi.org/10.1016/j.scitotenv.2019.01.245

49. Quaroni A, Kirsch K, Weiser MM (1979) Synthesis of membrane glycoproteins in rat small-intestinal villus cells. Redistribution of L-[1,5,6-3H] fucose-labelled membrane glycoproteins among Golgi, lateral basal and microvillus membranes in vivo. Biochem J 182:203-212. https://doi.org/10.1042/bj1820203

50. Rajeshkumar S, Li X (2018) Bioaccumulation of heavy metals in fish species from the Meiliang Bay, Taihu Lake, China. Toxicol Rep 5:288-295. https://doi.org/10.1016/j.toxrep.2018.01.007

51. Ring E, Jutfelt F, Kanapathippillai P, Bakken Y, Sundell K, Glette J, Mayhew TM, Myklebust R, Olsen RE (2004) Damaging effect of the fish pathogen Aeromonas salmonicida ssp. salmonicida on intestinal enterocytes of Atlantic salmon (Salmo salarL.). Cell Tissue Res 318:305-311. https://doi.org/10.1007/s00441-004-0934-2

52. Roopadevi H, Somashekar K R (2012) Assessment of the toxicity of waste water from a textile industry to Cyprinus carpio. J Environ Biol 33:167-171

53. Ruseler-van EJG, Van DHR, Van LLM (1989) Degradation of intestinal glycoproteins by Bacteroides vulgatus. FEMS Microbiol Lett 49:37-41. https://doi.org/10.1111/j.1574-6968.1989.tb03014.x

54. Sin SN, Chua H, Lo W, Ng LM (2001) Assessment of heavy metal cations in sediments of Shing Mun River, Hong Kong. Environ Int 26:297-301. https://doi.org/10.1016/S0160-4120(01)00003-4

55. Sivaperumal P, Sankar T, Viswanathannair $P$ (2007) Heavy metal concentrations in fish, shellfish and fish products from internal markets of India vis-a-vis international standards. Food Chem 102:612620. https://doi.org/10.1016/j.foodchem.2006.05.041

56. Tan X, Sun Z, Zhou C, Huang Z, Tan L, Xun P, Huang Q, Lin H, Ye C, Wang A (2018) Effects of dietary dandelion extract on intestinal morphology, antioxidant status, immune function and physical barrier function of juvenile golden pompano Trachinotus ovatus. Fish Shellfish Immunol 73:197-206. https://doi.org/10.1016/j.fsi.2017.12.020

Page $15 / 24$ 
57. Tao Y, Yuan Z, Xiaona H, Wei M (2012) Distribution and bioaccumulation of heavy metals in aquatic organisms of different trophic levels and potential health risk assessment from Taihu lake, China. Ecotox Environ Safe 81:55-64. https://doi.org/10.1016/j.ecoenv.2012.04.014

58. Vargas VM, Migliavacca SB, Melo AC, Horn RC, Guidobono RR, Isabel CFF, Maria HDP (2001) Genotoxicity assessment in aquatic environments under the influence of heavy metals and organic contaminants. Mutat Res 490:141-158. https://doi.org/10.1016/S1383-5718(00)00159-5

59. Xun P, Lin H, Wang R, Huang Z, Zhou C, Yu W, Huang Q, Tan L, Yun W, Wang J (2019) Effects of dietary vitamin B-1 on growth performance, intestinal digestion and absorption, intestinal microflora and immune response of juvenile golden pompano (Trachinotus ovatus). Aquaculture 506:75-83. https://doi.org/10.1016/j.aquaculture.2019.03.017

60. Yang L, Guell M, Niu D, George H, Lesha E, Grishin D, Aach J, Shrock E, Xu W, Poci J, Cortazio R, Wilkinson RA, Fishman JA, Church G (2015) Genome-wide inactivation of porcine endogenous retroviruses (PERVs). Science 350:1101-1104. https://doi.org/10.1126/science.aad1191

61. Yang HC, Im WT, Kim KK, An DS, Lee ST (2006) Burkholderia terrae sp. nov., isolated from a forest soil. Int J Syst Evol Microbiol 56:453-457. https://doi.org/10.1099/ijs.0.63968-0

62. Yuan G, Liu C, Chen L, Yang Z (2011) Inputting history of heavy metals into the inland lake recorded in sediment profiles: Poyang Lake in China. J Hazard Mater 185:336-345. https://doi.org/10.1016/j.jhazmat.2010.09.039

63. Wang J, Chen C (2015) The current status of heavy metal pollution and treatment technology development in China. Environ Technol Rev 4:39-53. https://doi.org/10.1080/21622515.2015.1051136

64. Wang X, Shen M, Zhou J, Jin Y (2019) Chlorpyrifos disturbs hepatic metabolism associated with oxidative stress and gut microbiota dysbiosis in adult zebrafish. Comp Biochem Physiol C: Pharmacol Toxicol Endocrinol 216:19-28. https://doi.org/10.1016/j.cbpc.2018.11.010

65. Zhang F, Berg M, Dierking K, Félix MA, Shapira M, Samuel B, Schulenburg H (2017) Caenorhabditis elegans as a model for microbiome research. Front Microbiol 8. https://doi.org/10.3389/fmicb.2017.00485

66. Zare S, Afaghi A, Heidari R, Asadpoor Y, Shiri S (2007) Effects of lead nitrate $\left(\mathrm{PbNO}_{3}\right)$ on the glucose and cortisol hormone levels in common carp, Cyprinus carpio. Pak J Biol Sci 10:15. https://doi.org/10.3923/pjbs.2007.2587.2590

\section{Figures}




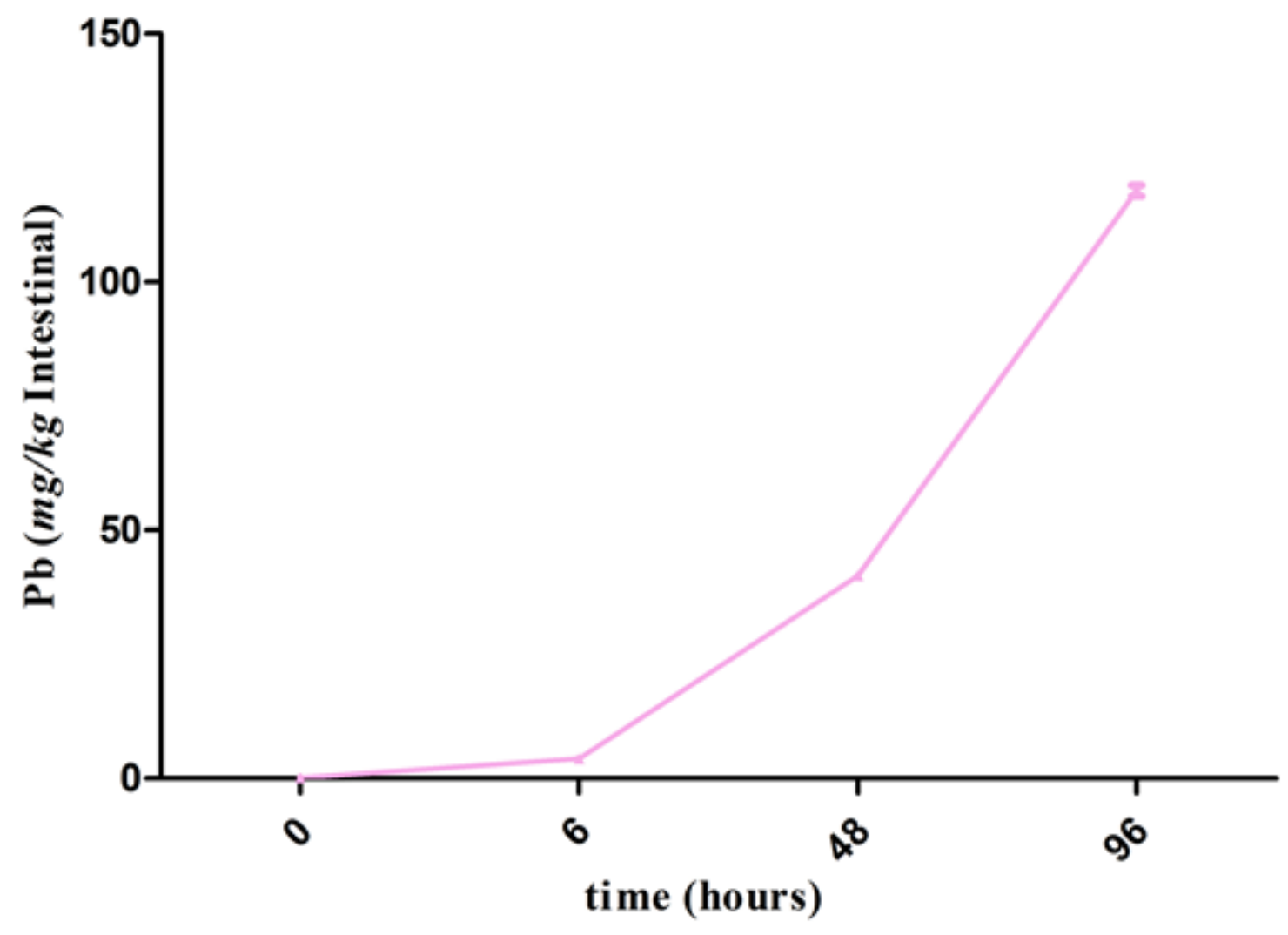

Figure 1

Accumulation of $\mathrm{Pb}$ in silver carp within $96 \mathrm{~h}$.

A
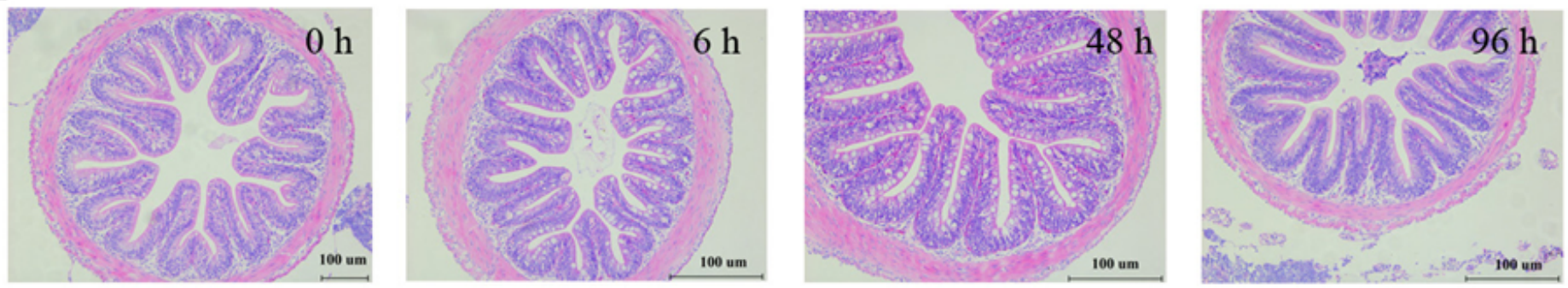

B

C

D
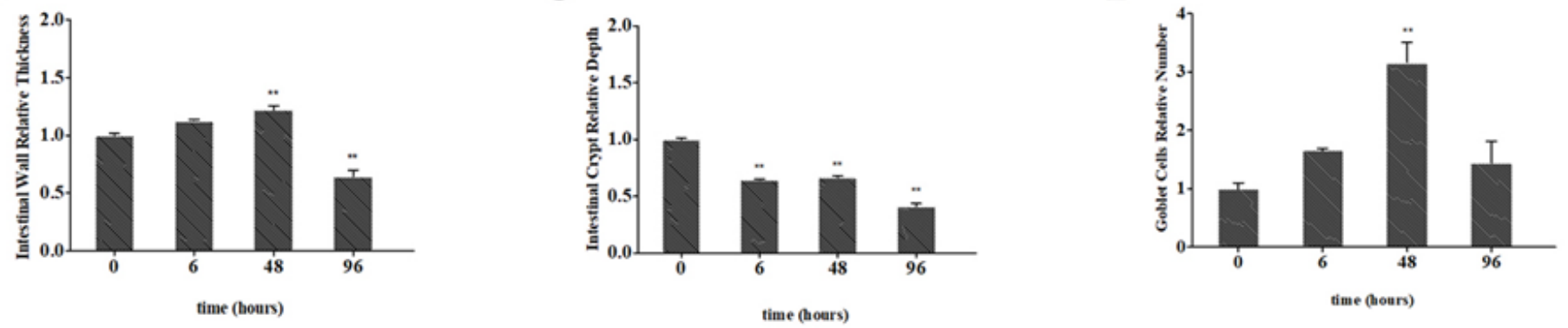

Figure 2 
Representative micrographs of intestines from silver carp (A). intestinal wall relative thickness (B), intestine crypt relative depth (C), and goblet cells relative number (D) were analyzed. Leukocyte infiltration occurs in the area indicated by the arrow. The asterisk represents a statistically significant difference $\left({ }^{*} 0.01<p<0.05\right.$ and $\left.{ }^{* *} p<0.01\right)$.

\section{A}

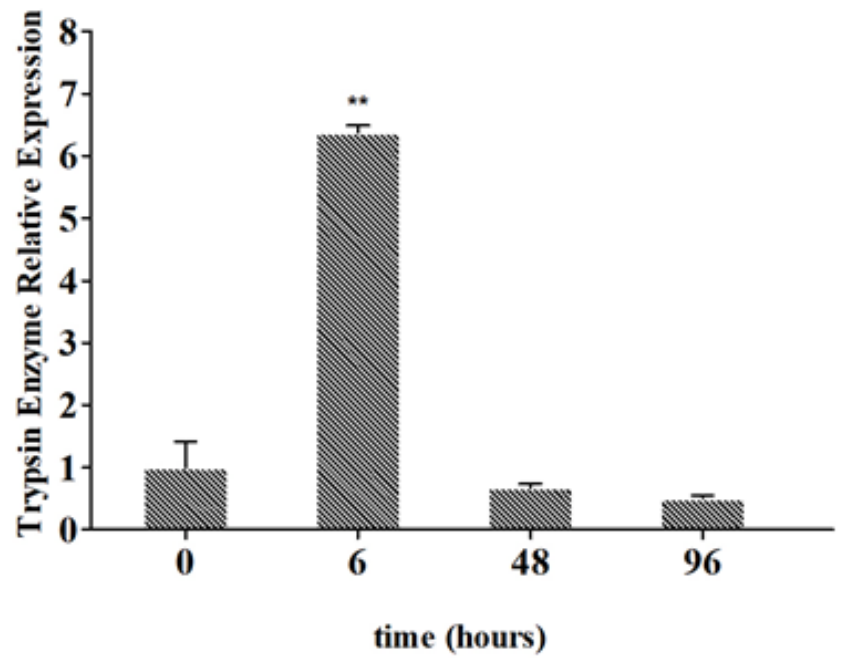

B

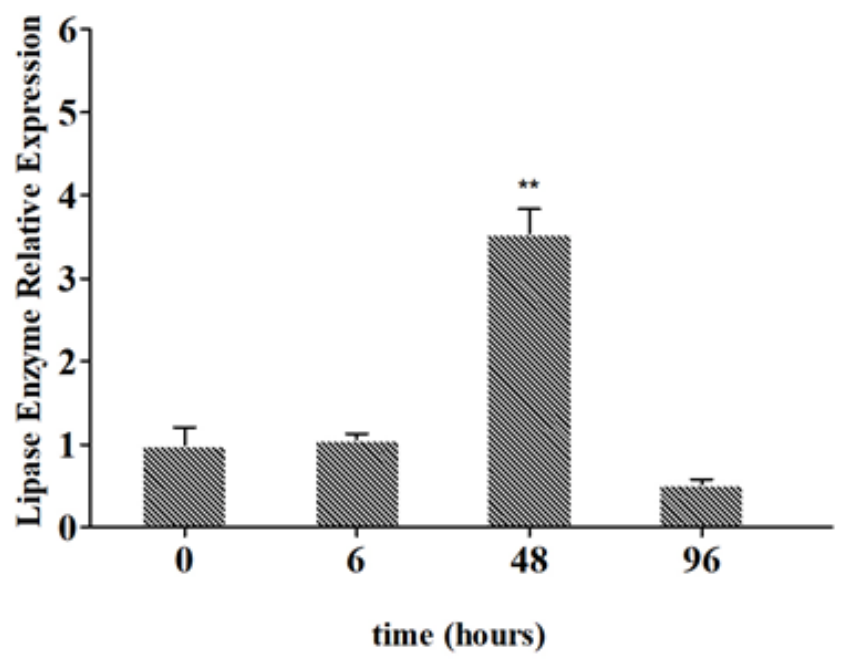

Figure 3

Relative enzyme activity of trypsin (A) and lipase (B) in silver carp intestines.

A

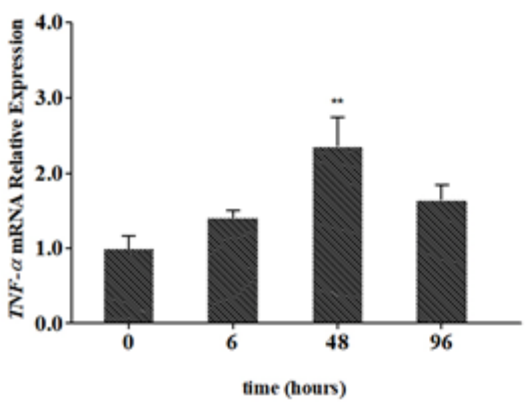

D

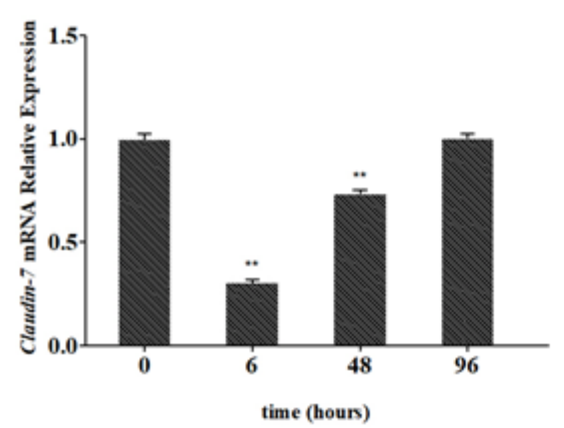

B

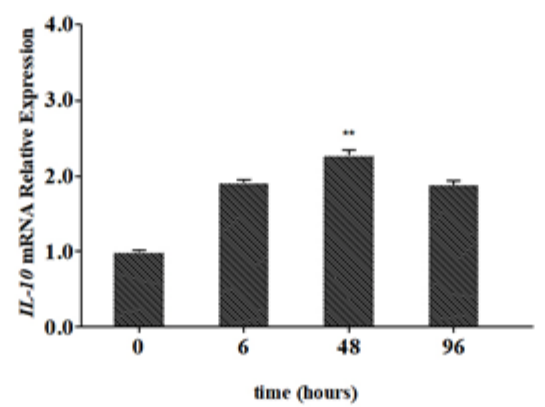

E

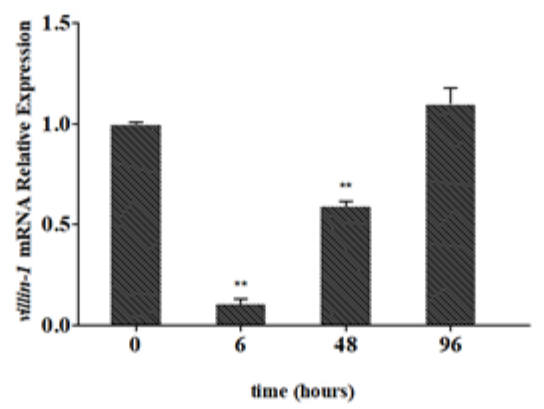

C

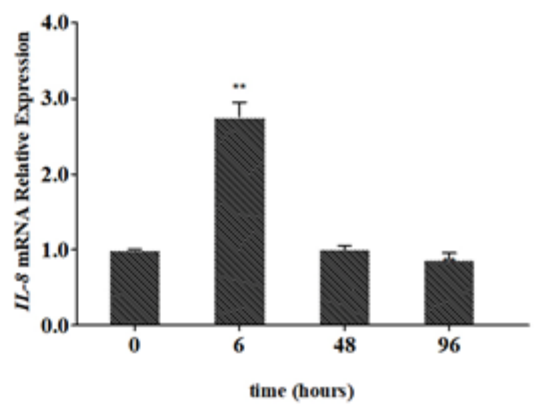

Figure 4 
Relative expression of TNF- $\triangle(A)$, IL-10 (B), IL-8 (C), Claudin-7 (D) and villin-1 (E) in the intestines of silver carp. The mRNA levels of each gene were normalized to that of $\beta$-actin. The asterisk represents a statistically significant difference $(* 0.01<p<0.05$ and $* * p<0.01)$.
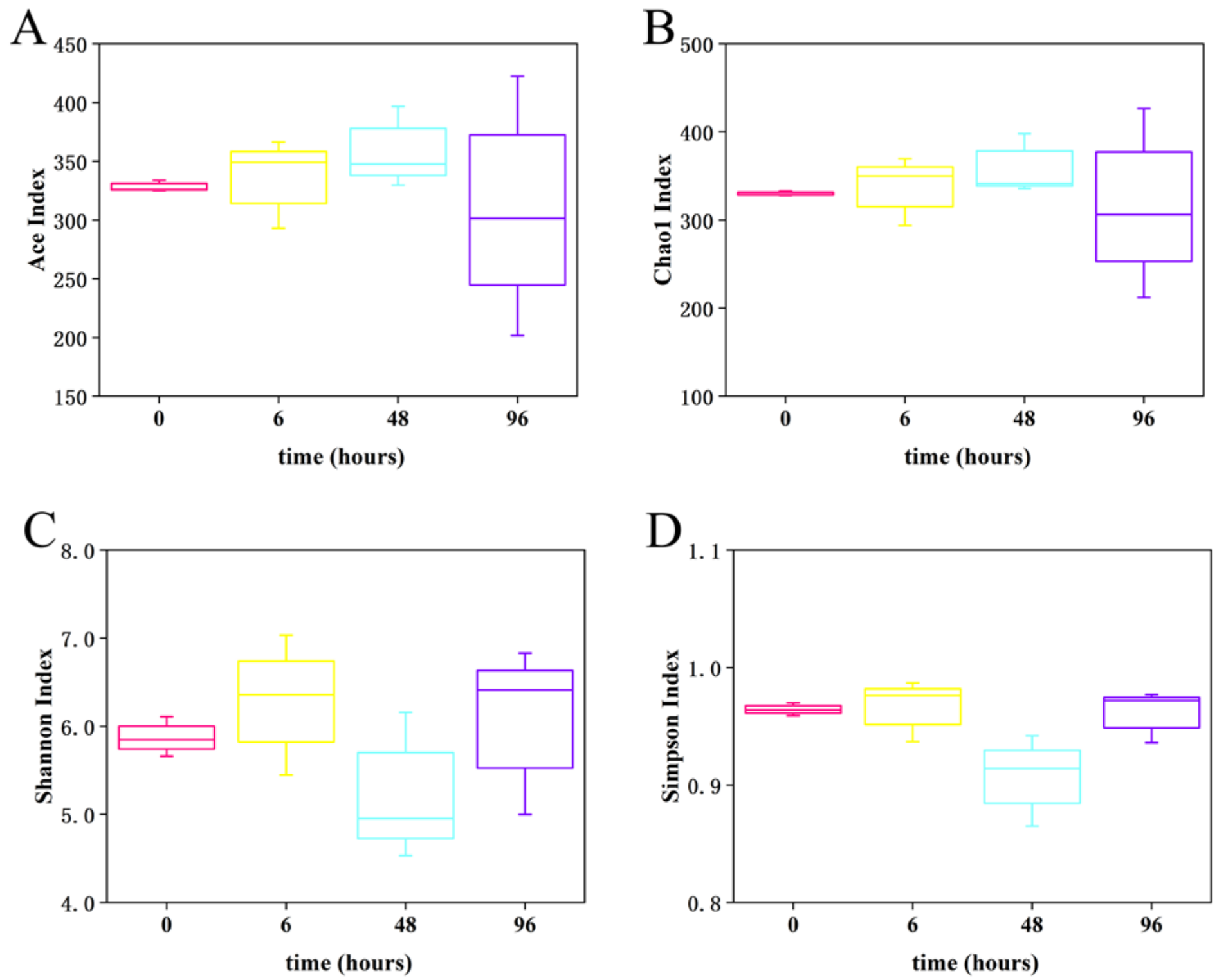

Figure 5

The effects of $\mathrm{Pb}$ on the richness and diversity of microbiota in the silver carp intestines in each sample. A. Ace index. B. Chao1 index. C. Shannon index. D. Simpson index. 


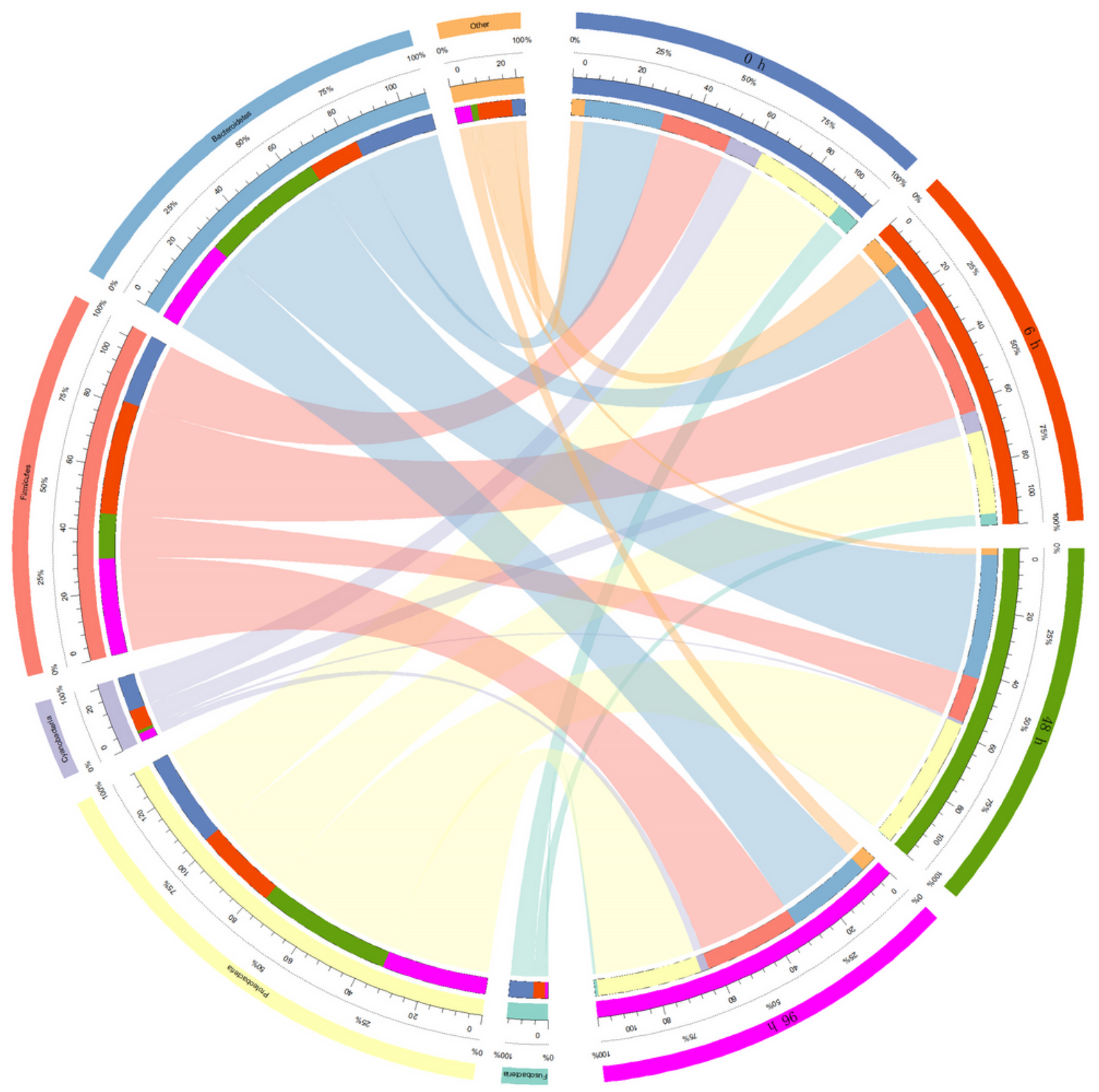

Figure 6

The intestinal microbiota composition of the silver carp's intestines at phylum level. 

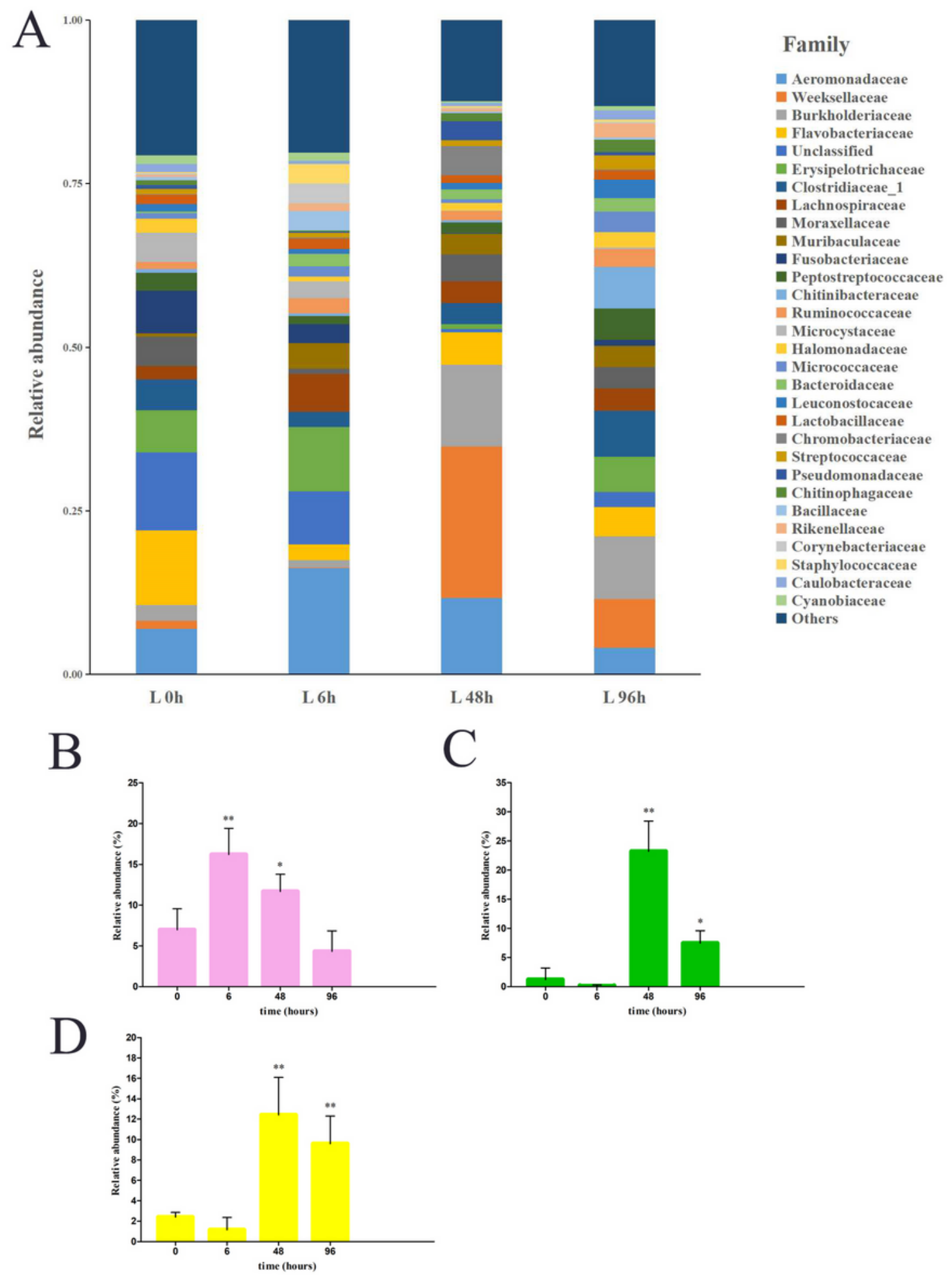

Figure 7

The effects of $\mathrm{Pb}$ exposure on the composition and relative abundance of microbiota silver carp's intestines (A) at the family level. Relative abundance of Aeromonadaceae (B), Weeksellaceae (C) and Burkholderiaceae (D) were measured. The asterisk represents a statistically significant difference $\left({ }^{\star} 0.01<\right.$ $p<0.05$ and $\left.{ }^{*} \mathrm{p}<0.01\right)$. 
A

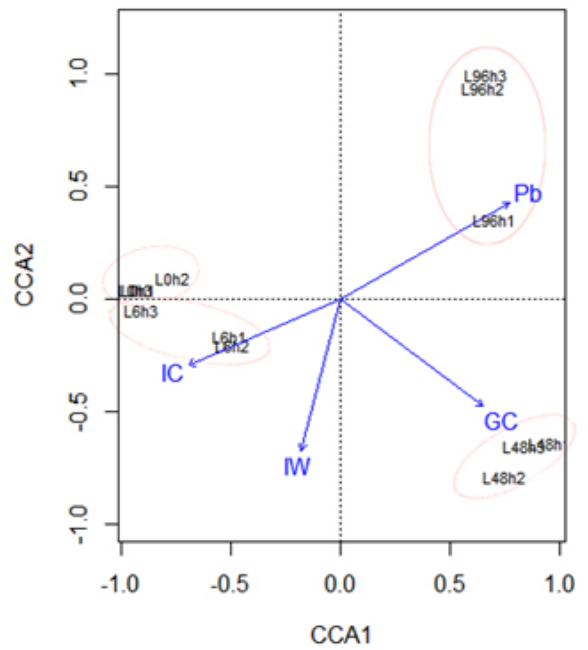

B

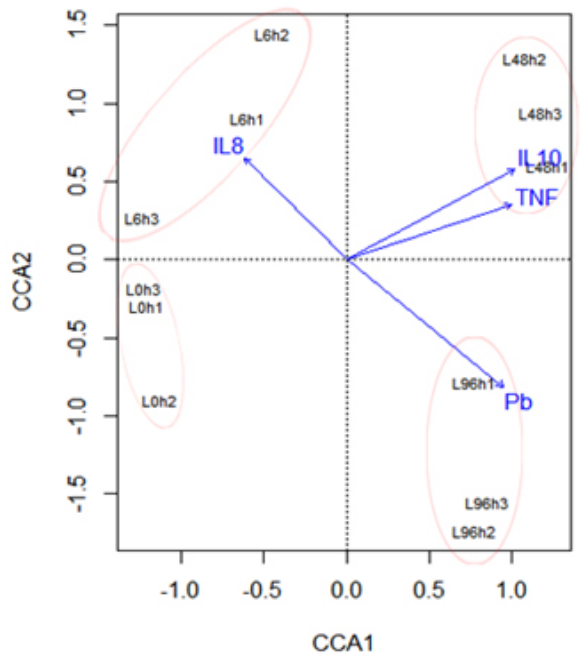

C

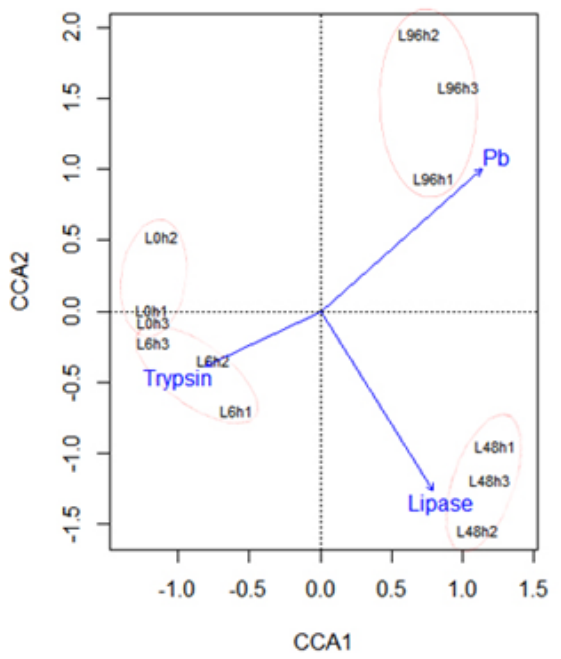

Figure 8

Canonical correlation analysis between intestinal microbial community structure of $\mathrm{H}$. molitrix and intestinal structure $(\mathrm{A})$, immune factors $(\mathrm{B})$, digestive factor $(\mathrm{C})$ and $\mathrm{Pb}$ content. 
A

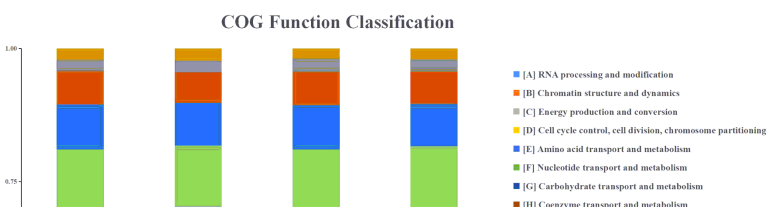

\section{Figure 9}

Functional prediction maps of all samples. A. he COG function classification of different groups. B. The KEGG function classification of the groups. C. Relative abundance changes of membrane transport in silver carp's intestines. D. Relative abundance changes of immune system in silver carp's intestines. E. Relative abundance changes of digestive system in silver carp's intestines. F. Relative abundance 
changes of cellular antigens in silver carp's intestines. Asterisk represents a statistically significant difference $\left({ }^{*} 0.01<p<0.05\right.$ and $\left.{ }^{* *} p<0.01\right)$. 